\title{
СОДЕРЖАНИЕ БЕЛКА В ЗЕРНЕ СОРТОВ ОЗИМОЙ ПШЕНИЦЫ ПРИ РАЗЛИЧНЫХ УРОВНЯХ МИНЕРАЛЬНОГО ПИТАНИЯ
}

\section{В. В. Кошеляев, доктор с.-х. наук, профрессор; В. И. Сальников*, аспирант; И. П. Кошеляева, доктор с.-х. наук, доцент}

\author{
Федеральное государственное бюджетное образовательное учреждение высшего \\ образования «Пензенский государственный аграрный университет», Россия, \\ т. 8(8412) 62-83-73, e-mail: agrocenter2005@yandex.ru \\ *Филиал фредерального государственного бюджетного учреждения \\ «Российский сельскохозяйственный центр» по Пензенской области, Россия, \\ т. 8(8412) 35-26-50, e-mail: rsc58@mail.ru
}

\begin{abstract}
Основным направлением повышения качества зерна является выведение новых сортов, генетически предрасположенных формировать зерно с высоким качеством. Вместе с тем, генетический потенциал сортов способен реализовываться только при конкретных погодных условиях и применении приемов возделывания, благоприятно влияющих на рост и развитие растений. В настоящих исследованиях путем изменения режимов питания растений создавали различные условия для того, чтобы определить возможности сортов формировать урожай зерна с большим содержанием белка. Цель работы - оценить и выделить сорта озимой пшеницы, способные реализовать потенциал качества зерна при различных уровнях интенсификации минерального питания. Для достижения цели был заложен двухфакторный полевой опыт. Фактор А - сорта озимой пшеницы, фактор В - уровни минерального питания. В результате установлено, что сорта озимой пшеницы характеризуются неодинаковыми свойствами накапливать белок в зерне. Высокой активностью накапливать белок при внесении удобрений характеризуется сорт Клавдия 2. Средней активностью сорта Безенчукская 380, Московская 56 и низкой Немчиновская 57, Скипетр и Фатинья. Внесение минеральных удобрений из расчета $\mathrm{N}_{16} \mathrm{P}_{16} \mathrm{~K}_{16}$ при посеве осенью и $\mathrm{N}_{68}$ в подкормку весной способствует формированию зерна с более высоким содержанием белка у всех сортов озимой пшеницы.
\end{abstract}

Ключевые слова: озимая пшеница, сорта, содержание белка, минеральное питание, удобрение.

\section{Введение}

Важным показателем качества является массовая доля белка в зерне. Многие литературные источники указывают, что основной фризиологической причиной, от которой зависит содержание белка в зерне, является количество азота в растении, приходящееся на единицу массы зрелого зерна. Оно может изменятся как от условий выращивания, так и от генотипа. Большая часть белка в зерне синтезируется в результате оттока азотистых веществ из вегетативных органов, накопленных в них к началу налива зерна, меньшая часть - за счет поглощения корнями из почвы в период налива [1-10].

Содержание белка в зерне является генетически зависимым признаком. В ряде работ показано, что причины, определяющие разный уровень накопления белка в зерне, состоят в следующем:

- количество азота в растении, приходящиеся на единицу массы зерна, или по- казатель обеспеченности зерна азотом (зависит от доли азота в урожае общей биомассы растения - уборочного индекса);

- концентрация азотистых веществ в вегетативных органах;

- способность растений к поглощению азота корнями в период налива зерна после цветения;

- реутилизация азотистых веществ вегетативных органов - полнота оттока в зерно;

- аттрагирующая способность колоса;

- способность зерновки к биосинтезу белка из небелкового азота [11-16].

Учитывая, что аттрагирующая способность колоса (то есть способность притягивать вещества) играет решающую роль в поступлении азотистых веществ в развивающиеся зерновки, то опосредованным показателем сортовой активности аттрагирования является содержание белка в зерне при различных уровнях минерального питания. Поэтому было целесообразным 
Содержание белка в зерне сортов озимой пшеницы при различных уровнях минерального питания, \%

\begin{tabular}{|c|c|c|c|c|c|c|}
\hline \multirow[b]{2}{*}{$\begin{array}{c}\text { Уровень минерального питания } \\
\text { (фрактор В) }\end{array}$} & \multicolumn{6}{|c|}{ Сорт (фактор A) } \\
\hline & 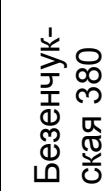 & 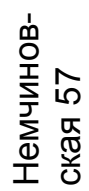 & $\begin{array}{l}\text { 童 } \\
\stackrel{5}{5} \\
\text { 竎 }\end{array}$ & 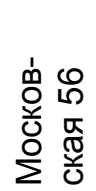 & $\begin{array}{l}\frac{\sigma}{0} \\
\stackrel{0}{T} \\
\stackrel{5}{\sigma} \\
\theta \\
\theta\end{array}$ & 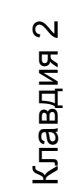 \\
\hline \multicolumn{7}{|c|}{2017 г. } \\
\hline Без удобрений & 12,2 & 11,8 & 10,8 & 11,4 & 11,3 & 11,8 \\
\hline $\mathrm{N}_{34}$ В подкормку & 13,9 & 12,9 & 11,8 & 13,2 & 11,5 & 14,0 \\
\hline $\mathrm{N}_{68}$ в подкормку & 13,2 & 12,7 & 12,0 & 12,7 & 11,7 & 14,1 \\
\hline $\mathrm{N}_{16} \mathrm{P}_{16} \mathrm{~K}_{16}$ при посеве & 12,8 & 11,4 & 12,2 & 12,8 & 12,3 & 12,3 \\
\hline $\mathrm{N}_{16} \mathrm{P}_{16} \mathrm{~K}_{16}$ при посеве + $\mathrm{N}_{34}$ в подкормку & 13,9 & 12,9 & 12,5 & 13,2 & 12,4 & 14,4 \\
\hline $\mathrm{N}_{16} \mathrm{P}_{16} \mathrm{~K}_{16}$ при посеве $+\mathrm{N}_{68}$ в подкормку & 13,7 & 13,0 & 12,4 & 13,5 & 12,4 & 14,6 \\
\hline \multicolumn{7}{|c|}{2018 г. } \\
\hline Без удобрений & 12,0 & 11,3 & 10,5 & 11,5 & 11,3 & 11,6 \\
\hline $\mathrm{N}_{34}$ В подкормку & 13,5 & 12,5 & 11,5 & 13,2 & 13,0 & 13,8 \\
\hline $\mathrm{N}_{68}$ в подкормку & 13,6 & 12,8 & 12,1 & 12,8 & 13,0 & 14,2 \\
\hline $\mathrm{N}_{16} \mathrm{P}_{16} \mathrm{~K}_{16}$ при посеве & 12,6 & 11,2 & 11,8 & 12,0 & 12,1 & 12,2 \\
\hline $\mathrm{N}_{16} \mathrm{P}_{16} \mathrm{~K}_{16}$ при посеве $+\mathrm{N}_{34}$ в подкормку & 13,8 & 12,6 & 12,2 & 13,0 & 12,6 & 14,0 \\
\hline $\mathrm{N}_{16} \mathrm{P}_{16} \mathrm{~K}_{16}$ при посеве $+\mathrm{N}_{68}$ в подкормку & 13,9 & 13,1 & 12,7 & 13,7 & 12,6 & 14,3 \\
\hline Без удобрений & 12,0 & 11,4 & 10,7 & 11,6 & 11,0 & 11,5 \\
\hline $\mathrm{N}_{34}$ В подкормку & 13,3 & 12,6 & 11,6 & 13,0 & 12,8 & 13,9 \\
\hline $\mathrm{N}_{68}$ в подкормку & 13,5 & 12,9 & 12,2 & 13,2 & 13,2 & 14,0 \\
\hline $\mathrm{N}_{16} \mathrm{P}_{16} \mathrm{~K}_{16}$ при посеве & 12,1 & 11,5 & 11,4 & 12,1 & 11,8 & 11,9 \\
\hline $\mathrm{N}_{16} \mathrm{P}_{16} \mathrm{~K}_{16}$ при посеве + $\mathrm{N}_{34}$ в подкормку & 13,5 & 12,6 & 11,9 & 13,2 & 12,9 & 14,0 \\
\hline $\mathrm{N}_{16} \mathrm{P}_{16} \mathrm{~K}_{16}$ при посеве $+\mathrm{N}_{68}$ в подкормку & 13,7 & 13,2 & 12,5 & 13,5 & 13,4 & 14,1 \\
\hline
\end{tabular}

рассмотреть сортовые особенности накопления белка в зерне.

\section{Методы и материалы}

Для достижения цели был заложен двухфакторный полевой опыт по следующей схеме:

Фактор А - сорта озимой пшеницы: Безенчукская 380 , Немчиновская 57 , Скипетр, Московская 56, Фатинья, Клавдия 2.

Фактор В - уровни минерального питания: 1 - без удобрений; $2-\mathrm{N}_{34}$ в подкормку; $3-\mathrm{N}_{68}$ в подкормку; $4-\mathrm{N}_{16} \mathrm{P}_{16} \mathrm{~K}_{16}$ при посеве; $5-\mathrm{N}_{16} \mathrm{P}_{16} \mathrm{~K}_{16}$ при посеве $+\mathrm{N}_{34}$ в подкормку; $6-\mathrm{N}_{16} \mathrm{P}_{16} \mathrm{~K}_{16}$ при посеве $+\mathrm{N}_{68}$ в подкормку.

Повторность опыта трехкратная. Расположение делянок систематическое. Предшественник - чистый пар.

Все сорта озимой пшеницы выращивались на едином фоне полной защиты растений от сорняков, болезней и вредителей. В качестве средств защиты применяли следующие препараты: гербицид Балерина, СЭ (0,5 л/га), инсектицид Борей, СК (0,1 л/га), фунгицид Колосаль ПРО, КМЭ (0,4 л/га).

Определение содержания белка в зерне проводили микроопределением по Биурету, колориметрическим методом, на приборе КФК-2 по методике Г.А. Кочетова (1971).

\section{Результаты}

Полученные результаты по годам исследований представлены в таблице 1.

Для того, чтобы установить зависимость накопления белка в зерне от генетических особенностей сорта проведен анализ изучаемого показателя на фоне выращивания без удобрений. В результате было установлено, что более высоким показателем содержания белка в зерне характеризовался сорт Безенчукская 380. Содержание белка в зерне составляло 12,0$12,2 \%$ в зависимости от года. Несколько ниже содержание белка в зерне формировалось у целой группы сортов. В зависимости от года исследований этот показатель колебался по сортам следующим образом: Немчиновская 57 - 11,3-11,8 \%, Московская 56 - 11,4-11,6\%, Клавдия 2 - 11,5$11,8 \%$ и Фатинья - 11,0-11,3\%. Более низким содержанием белка в зерне (10,510,8 \%), во все годы исследований, характеризовался сорт Скипетр. Можно предположить, что для этого сорта свойственна некоторая пониженная способность накапливать белок в зерне, по отношению к другим сортам.

Оценивая содержание белка в зерне на вариантах с внесением минеральных удобрений видно, что все сорта увеличи- 
Общая и специфическая способность накапливать белок в зерне у сортов озимой пшеницы в зависимости от применения минеральных удобрений

\begin{tabular}{|c|c|c|c|c|c|c|}
\hline \multirow[b]{2}{*}{$\begin{array}{c}\text { Уровень минерального питания } \\
\text { (фрактор В) }\end{array}$} & \multicolumn{6}{|c|}{ Сорт (фрактор A) } \\
\hline & $\begin{array}{c}\text { Безен- } \\
\text { чукская } \\
380\end{array}$ & \begin{tabular}{|c|} 
Немчи- \\
новская \\
57
\end{tabular} & $\begin{array}{l}\text { Ски- } \\
\text { петр }\end{array}$ & \begin{tabular}{|c|} 
Мос- \\
ковская \\
56
\end{tabular} & $\begin{array}{l}\text { Фа- } \\
\text { тинья }\end{array}$ & $\begin{array}{l}\text { Клав- } \\
\text { дия } 2\end{array}$ \\
\hline Без удобрений & $-0,5$ & $-1,1$ & $-1,9$ & $-1,1$ & $-1,4$ & $-1,0$ \\
\hline $\mathrm{N}_{34}$ в подкормку & 1,0 & 0,1 & $-1,0$ & 0,5 & $-0,2$ & 1,3 \\
\hline $\mathrm{N}_{68}$ в подкормку & 0,8 & 0,2 & $-0,5$ & 0,3 & 0,0 & 1,5 \\
\hline $\mathrm{N}_{16} \mathrm{P}_{16} \mathrm{~K}_{16}$ при посеве & $-0,1$ & $-1,2$ & $-0,8$ & $-0,3$ & $-0,5$ & $-0,5$ \\
\hline $\mathrm{N}_{16} \mathrm{P}_{16} \mathrm{~K}_{16}$ при посеве $+\mathrm{N}_{34}$ в подкормку & 1,1 & 0,1 & $-0,4$ & 0,5 & 0,0 & 1,5 \\
\hline $\mathrm{N}_{16} \mathrm{P}_{16} \mathrm{~K}_{16}$ при посеве $+\mathrm{N}_{68}$ в подкормку & 1,2 & 0,5 & $-0,1$ & 1,0 & 0,2 & 1,7 \\
\hline $\begin{array}{l}\text { Сумма отклонений (общая способность } \\
\text { накапливать белок в зерне) }\end{array}$ & 3,5 & $-1,4$ & $-4,7$ & 0,9 & $-1,9$ & 4,5 \\
\hline
\end{tabular}

вали содержание белка в зерне при весенних подкормках, как на фроне внесения $\mathrm{N}_{16}$ $\mathrm{P}_{16} \mathrm{~K}_{16}$ при посеве осенью, так и без внесения N P К. Повышение белка в зерне, по отношению к варианту, где удобрения не вносили составляло: Безенчукская 380 1,0-1,7 \%, Немчиновская 57 - 0,9-1,2 \%, Скипетр - 1,0-1,7\%, Московская 56 - 1,3$2,1 \%$, Фатинья - 1,6-2,5\%, Клавдия 2 2,2-2,8 \%. Из приведенных данных следует, что при внесение весенних подкормок более высокий рост белка характерен для сорта Клавдия 2. Содержание белка в зерне этого сорта при весенних подкормках было самое высокое и составляло 14,014,6 \% в зависимости от года и вариантов.

Для оценки сортовой способности накапливать белок в зерне на различных вариантах опыта мы исходили из того, что среднее содержание белка в зерне $(\mathrm{X})$ по сортам, вариантам опыта и годам исследований включает все различия белковости. Поэтому сумма отклонений от среднего значения содержания белка в зерне по опыту (с положительным или отрицательным знаком) конкретного сорта по вариантам применения удобрений характеризует общую способность сорта накапливать белок под влиянием удобрений. Отклонение значения содержания белка на конкретном варианте от среднего значения содержания белка в опыте конкретного сорта характеризует специфическую способность данного сорта накапливать белок в зерне. Полученные результаты приведены в таблице 2.

Анализируя данные таблицы видно, что более высокой положительной общей способностью накапливать белок в зерне характеризуется сорт Клавдия 2. Соответственно, способность колоса притягивать азотистые вещества при внесении удобрений у данного сорта возрастает в больше мере, чем у других сортов, что указывает на характерное сортовое свойство. Несколько ниже положительная общая способность накапливать белок в зерне при внесении удобрений у сортов Безенчукская 380 и Московская 56. Отрицательной общей способностью накапливать белок в зерне характеризовались сорта Немчиновская 57, Скипетр и Фатинья. Соответственно, для этих сортов характерна меньшая интенсивность синтеза белка в зерне при внесении удобрений. Более сильно это свойство выражено у сорта Скипетр.

Оценивая специфическую способность сортов накапливать белок в зерне видно, что более активно синтез белка проявляется у всех сортов на варианте опыта, где вносили $\mathrm{N}_{16} \mathrm{P}_{16} \mathrm{~K}_{16}$ при посеве осенью и $\mathrm{N}_{68}$ в подкормку весной.

\section{Заключение}

Сорта озимой пшеницы характеризуются неодинаковыми свойствами накапливать белок в зерне. Высокой активностью накапливать белок при внесении удобрений характеризуется сорт Клавдия 2. Средней активностью сорта Безенчукская 380, Московская 56 и низкой Немчиновская 57, Скипетр и Фатинья.

Внесение минеральных удобрений из расчета $\mathrm{N}_{16} \mathrm{P}_{16} \mathrm{~K}_{16}$ при посеве осенью и $\mathrm{N}_{68}$ В подкормку весной способствует формированию зерна с более высоким содержанием белка у всех сортов озимой пшеницы. 


\section{Лumepamypa}

1. Говолоченко, А. П. Белковый комплекс хлебопекарной пшеницы Среднего Поволжья: монография / А. П. Говолоченко, М. Ю. Киселева. - Самара, 2005. - 212 с.

2. Елисеев, В. И. Зависимость содержания белка в зерне яровой мягкой пшеницы от систематического внесения различных доз минеральных удобрений / В. И. Елисеев // Известия Оренбургского государственного аграрного университета. - 2017. - № 2 (64). - С. 14-16.

3. Бакаева, Н. П. Суммарное содержание белка в зерне озимой пшеницы в зависимости от предпосевной обработки зерна препаратом «Стимулайф» и подкормки классическими удобрениями / Н. П. Бакаева, Н. Ю. Коржавина // Агротехнический метод защиты растений от вредных организмов: сборник материалов VII Международной научно-практической конференции. - 2015. - C. $19-21$

4. Бакаева, Н. П. Влияние предшественников, способов основной обработки почвы и удобрений на урожайность и биохимические показатели качества зерна озимой и яровой пшеницы в условиях лесостепи Среднего Поволжья / Н. П. Бакаева, О. Л. Салтыкова // Успехи современного естествознания. - 2007. - № 12. - С. 19-23.

5. Бакаева, Н.П.Влияние применения удобрений при выращивании пшеницы на получение белка и крахмала / Н. П. Бакаева, О. Л. Салтыкова, Н. Ю. Коржавина // Химия в сельском хозяйстве: сборник материалов Всероссийской научно-практической конфреренции (2-6 июня 2014г.): для студентов и аспирантов. - Уфа: Башкирский ГАУ, 2014. - С. 203-207.

6. Салтыкова, О. Л. Влияние предшественников, обработки почвы и удобрений на урожайность и биохимические показатели качества зерна яровой пшеницы в лесостепи Заволжья / О. Л. Салтыкова // Научно-аналитический журнал: научная перспектива. - 2010. - № 3-4. - С. 124 -126 .

7. Влияние систем удобрений на химический состав растений и технологические показатели зерна озимой пшеницы /Т.С.Айсанов, А. Н. Есаулко, М. С. Сигида, Е.В.Голосной, С. А. Коростылев // Проблемы развития АПК региона. - 2015. - Т. 23. - № 3 (23). - С. 4-7.

8. Попов, С. И. Формирования качества зерна пшеницы озимой в зависимости от погодных условий года и фона питания в восточной части лесостепи Украины / С.И. Попов, С. В. Авраменко // Аграрный вестник Юго-Востока. - 2013. - № 1-2 (8-9). - С. 18-19.

9. Эллерт, Д. Ю. Накопление нитратов в растениях и качество озимой пшеницы при систематическом применении удобрений (в условиях Топчихинского района Алтайского края) / Д. Ю. Эллерт, Е.В.Райхерт // Известия Алтайского государственного университета. - 2014. № 3-1 (83). - C. 110-113.

10. Бакаева, Н. П. Динамика азота и формирование белковой продуктивности пшеницы при различных технологиях возделывания / Н. П. Бакаева, О. Л. Салтыкова, В. М. Царевская // Известия Самарской государственной сельскохозяйственной академии. - 2018. - № 4. - С. 3-9.

11. Бебякин, В. М. Содержание, распределение и реутилизация азота в органах растений яровой мягкой пшеницы, различающихся по содержанию белка в зерне / В. М. Бебякин, Д.В.Кайргалиев // Сельскохозяйственная биология. - 2004. - Т. 39. - № 5. - С. 68-75.

12. Аттрагирующая способность колоса пшеницы, выращенной в разных экологических и агротехнических условиях / М.М.Рахимов, М.Б. Ниязмухамедова, Е.А.Гулов, М. Пулодов, Н. Камолов, Ф. А. Косумбекова // Доклады Академии наук Республики Таджикистан. - 2011. - Т. 54. - № 6. - С. 504-508.

13. Галушко, Н. А. Аттрагирующая способность колоса сортов озимой пшеницы в зависимости от удобрений и сроков сева / Н. А. Галушко // Сборник трудов молодых ученых: Российская академия сельскохозяйственных наук, Государственное научное учреждение Ставропольский научно-исследовательский институт сельского хозяйства. - Ставрополь, 2010. - С. 10-14.

14. Коржавина, Н. Ю. Аттрагирующая способность колоса и структура урожая озимой пшеницы на фроне применения микроудобрений жусс / Н. Ю. Коржавина, Н. П. Бакаева // Вклад молодых ученых в аграрную науку: сборник материалов Международной научно-практической конфреренции. Самарская ГСХА. - Самара, 2016. - С. 88 - 89.

15. Abad, A. Nitrogen fertilization and foliar urea effects on durum wheat yield and quality and on residual soil nitrate in irrigated Mediterranean conditions / A. Abad, J. Lloveras, A. Michelena // Field Crops Research. - 2004. - 87 (2-3) - - C. 257-269.

16. Järvan, $M$. The content and quality of protein in winter wheat grains depending on sulphur fertilization / M. Järvan, L. Adamson // Acta Agriculturae Scandinavica Section B: Soil and Plant Science. 2012. - 62 (7). - C. 627-636. 
UDC $633.63+631.82$

DOI: 10.36461/NP.2019.52.3.004

\title{
PROTEIN CONTENT IN GRAINS OF WINTER WHEAT VARIETIES AT DIFFERENT LEVELS OF MINERAL NUTRITION
}

\author{
V. V. Koshelyaev, Doctor of Agricultural Sciences, professor; V. I. Salnikov", postgraduate; \\ I. P. Koshelyaeva, Doctor of Agricultural Sciences, assistant-professor
}

Federal State Budgetary Educational Institution of Higher Education «Penza State Agrarian University», Russia, t. 8(8412) 62-83-73, e-mail: agrocenter2005@yandex.ru

*Branch of the Federal State Budgetary Institution «Russian Agricultural Center» in the Penza Region, Russia, t. 8(8412) 35-26-50, e-mail: rsc58@mail.ru

The main direction of improving the quality of grain is the cultivation of new varieties genetically predisposed to form high quality grain. At the same time, the genetic potential of varieties can only be realized under specific weather conditions and the application of cultivation techniques that favourably affect the growth and development of plants. In these studies, various conditions were created by changing plant nutritional regimes in order to determine the possibilities of varieties to form a grain crop with a high protein content. The purpose of the work was to evaluate and highlight varieties of winter wheat that can realize the potential of grain quality at various levels of intensification of mineral nutrition. To achieve the goal, a two-factor field experiment was carried out. Factor A - winter wheat varieties, factor B - levels of mineral nutrition. As a result, it was established that varieties of winter wheat were characterized by unequal properties to accumulate protein in grain. Variety Claudia 2 was characterized by high activity to accumulate protein when fertilizing. Bezenchukskaya 380, Moskovskaya 56 were characterized by medium activity and Nemchinovskaya 57, Scepter and Fatigna - by low. The application of mineral fertilizers at the rate of N16 P16 K16 during sowing in fall and N68 for top dressing in spring contributed to the formation of grain with a higher protein content in all varieties of winter wheat.

Key words: winter wheat, varieties, protein content, mineral nutrition, fertilizer.

References:

1. Govolochenko, A. P. Protein complex of baking wheat of the Middle Volga region: monograph / A. P. Govolochenko, M. Yu. Kiseleva. - Samara, 2005.-- 212 p.

2. Eliseev, V. I. The dependence of the protein content in the grain of spring soft wheat from the systematic application of various doses of mineral fertilizers / V. I. Eliseev // Bulletin of the Orenburg State Agrarian University. - 2017. - No. 2 (64). - p. 14-16.

3. Bakaeva, N.P. The total protein content in winter wheat grain, depending on the pre-sowing treatment of grain with the "Stimulife» preparation and top dressing with classical fertilizers / N. P. Bakaeva, N. Yu. Korzhavina // Agrotechnical method of protecting plants from pests: a collection of materials of the VII International Scientific and Practical Conference. - 2015. - p. 19-21

4. Bakaeva, N. P. The influence of forecrops, of methods of primary tillage and of fertilizers on productivity and biochemical quality indicators of grain of winter and spring wheat in the forest-steppe of the Middle Volga region / N. P. Bakaeva, O. L. Saltykova // Successes in modern science. - 2007. - No. 12. p. 19-23.

5. Bakaeva, N.P. The effect of the use of fertilizers in growing wheat on the production of protein and starch / N. P. Bakaeva, O. L. Saltykova, N. Yu. Korzhavina // Chemistry in Agriculture: a collection of materials of the All-Russian Scientific and Practical Conference (June 2-6, 2014): for students and graduate students. - Ufa: Bashkir State Agrarian University, 2014.-- p. 203-207.

6. Saltykova, O. L. The influence of forecrops, tillage and fertilizers on productivity and biochemical quality indicators of spring wheat grain in the forest-steppe of the Volga region / O. L. Saltykova // Scientific and analytical journal: scientific perspective. - 2010. - No. 3-4. - p. $124-126$.

7. The influence of fertilizer systems on the chemical composition of plants and technological parameters of grain of winter wheat / T. S. Aisanov, A. N. Yesaulko, M. S. Sigida, E. V. Golosnoy, S. A. Korostylev // Problems of the development of agribusiness in the region. - 2015. - V. 23. - No. 3 (23). - p. 4-7.

8. Popov, S. I. Formation of the quality of winter wheat grain depending on weather conditions of the year and nutrition background in the eastern part of the forest-steppe of Ukraine / S. I. Popov, S. V. Avramenko // Agrarian Bulletin of the South-East. - 2013. - No. 1-2 (8-9). - p. 18-19.

9. Ellert, D. Yu. The accumulation of nitrates in plants and the quality of winter wheat during the systematic use of fertilizers (in the conditions of Topchikhinsky district of the Altai Territory) / D. Yu. Ellert, E. V. Reichert // News of Altai State University. - 2014. - No. 3-1 (83). - p. 110-113. 
10. Bakaeva, N. P. Dynamics of nitrogen and formation of protein productivity of wheat with various cultivation technologies / N. P. Bakaeva, O. L. Saltykova, V. M. Tsarevskaya // Bulletin of the Samara State Agricultural Academy. - 2018. - No. 4. - p. 3-9.

11. Bebyakin, V. M. The content, distribution and recycling of nitrogen in the organs of spring soft wheat plants, differing in the protein content in the grain / V. M. Bebyakin, D. V. Kayrgaliev // Agricultural biology. - 2004. - V. 39. - No. 5. - p. 68-75.

12. The attracting ability of an ear of wheat grown in different environmental and agricultural conditions / M. M. Rakhimov, M. B. Niyazmukhamedova, E. A. Gulov, M. Pulodov, N. Kamolov, F. A. Kosumbekova // Reports of the Academy of Sciences of the Republic of Tajikistan. - 2011. - T. 54. - No. 6. p. 504-508.

13. Galushko, N. A. The attracting ability of an ear of winter wheat varieties depending on fertilizers and sowing dates / N. A. Galushko // Proceedings of young scientists: Russian Academy of Agricultural Sciences, State Scientific Institution Stavropol Agricultural Research Institute. - Stavropol, 2010.-- p. 1014.

14. Korzhavina, N. Yu. The attracting ability of an ear and the structure of a crop of winter wheat against the background of the use of liquid microfertilizer stimulants / N. Yu. Korzhavina, N. P. Bakaeva // Contribution of young scientists to agricultural science: a collection of materials of the International scientific and practical conference. Samara State Agricultural Academy. - Samara, 2016.-- p. 88 - 89.

15. Abad, A. Nitrogen fertilization and foliar urea effects on durum wheat yield and quality and on residual soil nitrate in irrigated Mediterranean conditions / A. Abad, J. Lloveras, A. Michelena // Field Crops Research. - 2004. - 87 (2-3). - p. 257-269.

16. Järvan, $M$. The content and quality of protein in winter wheat grains depending on sulphur fertilization / M. Järvan, L. Adamson // Acta Agriculturae Scandinavica Section B: Soil and Plant Science. 2012. -62 (7). - p. 627-636. 